RESENHA/BOOK REVIEW

\title{
INSPIRING FELLINI: LITERARY COLLABORATIONS BEHIND THE SCENES
}

Pacchioni, F. (2014) Inspiring Fellini: Literary Collaborations Behind the Scenes. Toronto: University of Toronto Press. 256p. ISBN: 1442612924.

By Cassiano Teixeira de Freitas Fagundes ${ }^{1^{*}}$ ${ }^{1}$ Universidade Federal de Santa Catarina, Florianópolis, SC, Brazil Evely Roberta Nimmo ${ }^{2^{* *}}$
${ }^{2}$ Universidade Estadual de Ponta Grossa, Ponta Grossa, PR, Brazil As Dr. Pacchioni points out, challenging the critics' portrayal of Frederico Fellini (1920 - 1993) as an autonomous creative force is a difficult task. Not only does the "critical institution" of auteurism fiercely defend the established image of the solitary and genial auteur, but the screenplay continues to be an underrated element both as a tool and a piece of art. Inspiring Fellini: Literary Collaborations Behind the Scenes (Toronto: University of Toronto Press. 256p. ISBN: 1442612924) confers a higher status to the film script by seeing it as part of a web of connections involving a rich literary and artistic context. The study also places the Italian director in a complex meshwork of collaborations that does not entirely downplay the traditional critical notions of his lone wolf geniality. On the contrary, as noted by one of his collaborators (160), his effective "absorption" of some of the best writers of the twentieth century testifies his own brand of auteurism. Was this practice a natural collaborative disposition or a resource that a creator of his stature could use without challenging his status as solitary mastermind? Pacchioni's investigation goes beyond definitive answers and examines the grey areas that dominate the creation of the director's unique cinematic vision.

The scholarly study proceeds to suspend the auteurism discourse of institutional criticism, which much to his collaborators' dismay echoed Fellini's own, and dives into the untold depths of his partnerships. The first finding appears to be the importance

\footnotetext{
${ }^{*}$ Doctoral student in Translation Studies at Programa de Pós-graduação em Estudos da Tradução (PGET) at UFSC, a program from which he also holds a Master's degree. Member of the Núcleo de Estudos do Processo Criativo (NUCPROC) at UFSC. He also holds a non-thesis M.A. in English, i.e., Teaching Methodology and Translation (PUC-PR).

${ }^{* *}$ Postdoctoral researcher in History at Universidade Estadual de Ponta Grossa, and affiliated researcher at Museu Paranaense, Curitiba (PR). She holds a Doctorate in Archeology from the University of Reading (2008), a Master's in Archeology from Simon Fraser University (2003) and an undergraduate degree in Anthropology and English from the University of Waterloo (2000).
} 
that his association with other artists had in his exploration of philosophic, mystic and esoteric matters.

This is most evident in his association with Tullio Pinelli, which is fittingly covered in the first chapter, thus setting the tone for the whole book. Pinelli was a writer and playwright known for his Catholic sensibilities and plays rich in tragic atmosphere. Working with Fellini at Lux Films from 1947 until the 1950s, the duo co-wrote screenplays for directors such as Alberto Lattuada and Pietro Germi, creating and honing a collaboration that would later produce the scripts for Fellini's La strada (1954) and La dolce vita (1960), among others. From the onset, the interest in esotericism was common ground, although Fellini's was a more eclectic sense of the spiritual, whereas Pinelli's had a Catholic tone. Pacchioni highlights another element of distinction between the two: Fellini often avoided representing violence and death in his movies, and the director had to counterbalance the tragic colors of Pinelli's dramaturgy, which Pacchioni exemplifies with the case of La strada.

Pinelli wrote the film's earliest script independently after some creative exchanges with Fellini. In this text, the character Il Matto is violently killed by Zampanò, a scene that was softened by the director, who in Pacchioni's words turns the event into the result of an "unpropitious misjudgment of force" (27). On the other hand, Fellini preserves Pinelli's lyrical use of landscapes, a testament to their shared pursuit of psychic depth. Pacchioni also notes how, although based on Christian sensibilities, Pinelli's interest in the supernatural strongly influenced Fellini. The chapter includes an excerpt from the ending of his play Lotta con langelo (1942) to show how his artistic views resonate in La strada. The author also covers their collaboration in $L a$ voce della luna (1990) and other projects.

Chapter two explores his collaboration with Ennio Flaiano, whose critical stance on neo-realism appeased Fellini's more progressive tendencies on plot structures. Flaiano helped with La strada's screenplay and wrote its dialogues, but his collaboration was more central in subsequent films. His "compassionate satire" influenced Fellini, who shared with him an ironic view of life. The vibrant and chaotic capital of Rome seemed to the two Adriatic natives the perfect backdrop to stage their partnership, which gave birth to La dolce vita, a film, in Flaiano's words in a letter to Fellini, with "great narrative freedom" (63). However, artistic, and especially authorship, issues plagued the turbulent collaboration that also spawned Le notti di Cabiria (1957) and 812/2 (1963).

The next chapter is devoted to Fellini's rebirth after a three-year hiatus that began in 1965 with the dissolution of his team of screenwriters. The agent of his comeback was Bernardino Zapponi. Unlike Pinelli and Flaiano who had recognition in the literary world, Zapponi was less well known and more connected with popular genres, which helped to materialize Fellini's focus on pop culture. Elements of Zapponi's collage-style experiments are in the scripts produced during their tenyear collaboration and influenced films such as Fellini Satyricon (1969) and Il 
Casanova di Frederico Fellini (1976). According to Pacchioni, during this period, the function of scripts changed and served more as a "collection of themes and motifs to be elaborated at a later stage" (83).

Given the specificities of his collaborations with Brunello Rondi, Pier Paolo Pasolini, Tonino Guerra and Andrea Zanzotto, chapter four begins with a description of the historical and sociocultural backgrounds of these partnerships, an element that could have been better explored in the preceding chapters. Pacchioni begins by noting that Italy in the 1950s was rapidly transitioning from a rural in an urban society that was heavily influenced by the United States. This change produced uneasiness, and Italians started to long for the more familiar world of their childhood. Hence, perspectives created with these poets have elements akin to a nostalgic idealization of that old reality, which are translated through the use of music, feminine images and a pregrammatical employment of language, as found in Casanova and Notti di Cabiria. Rondi was instrumental in helping the development of the character Steiner in La dolce vita. In Pasolini, Fellini had a partner with the self-critical rigor that he lacked and streetwise knowledge of substandard Italian, repaying him with an immersion in his metamorphous creative world. Guerra's presence in Amarcord (1973) can be seen in poetic childhood memories and atmospheres, and Zanzotto brought his intellectual coherence to counterbalance the director's unbridled, but skilled, creativity.

Pacchioni's research focuses on artistic synergy in Italian Cinema, Literature, and Theatre, and Inspiring Fellini is a groundbreaking scholarly study with many qualities, the greatest of which is the revelation of numerous contextualized interplays. It is the result of a very well-documented narrative based on Fellini's collaborators' own bodies of work as creative and aesthetic sources. The meticulous research includes differing versions of scripts and the films' literary backgrounds, partnership conversations both in public and in private, the subjective insights of Fellini's notes and sketches that would shape his works, and the historical significance behind his collaborative accomplishments. Additionally, the combination of illustrations from Fellini's Book of Dreams (2008) and revealing information pertaining to his collaborative genetic process allows the reader to have unique insights into the artists' creative genius. However, a caveat is necessary concerning the deconstruction of Fellini's solitary auteur image. Although the book acknowledges the importance of his collaborative work with writers and poets, it does not challenge the perception of an auteur deeply focused on his own artistic vision, who drew from other artists' visions without losing his own. 


\section{References}

Bondanella, P. A History of Italian Cinema. New York: Bloomsbury Publishing, (2009).

Pacchioni, F. Inspiring Fellini: Literary Collaborations Behind the Scenes. Toronto: University of Toronto Press, (2014).

Recebido em: 15/11/2017

Aceito em: 27/03/2018 